\title{
Helligånden, Guds røst på jord
}

\author{
Af Morten Mortensen
}

I Grundtvigs teologi spiller Helligånden en afgørende rolle. Både pinsesalmerne og salmerne om kirken vidner om, at den tredje trosartikel er en levende virkelighed for Grundtvig, og de mere end 2000 gange, ordet "Aand " forekommer i Sangværket, vidner om, at det har ligget Grundtvig stærkt på sinde at formidle denne virkelighed til sin samtid. En nærmere undersøgelse viser da også hurtigt, at Grundtvigs teologi ville være umulig uden troen på den tredje person i den treenige guddom.

Som en naturlig følge af, at Grundtvig tillægger helligåndstroen denne store rolle, må han gang på gang klage over samtidens svage tro på Åndens person og manglende forståelse for Åndens virksomhed i skabelsen, opholdelsen, genløsningen og fuldendelsen. Den svage tro på og manglende forståelse for Helligåndens person og gerning er efter Grundtvigs udsagn én af de væsentligste årsager til de sørgelige tilstande, han finder i kirken.

Således er der allerede to grunde til at gå i gang med en undersøgelse af Grundtvigs helligåndsteologi. Den ene er undersøgelsens nødvendighed for selve Grundtvigforskningen, idet en forståelse af Grundtvigs tænkning i det hele taget kræver en indsigt i hans helligåndsteologi. Den anden grund til undersøgelsen kommer af Grundtvigs egen understregning af helligåndsteologiens betydning for vor guds- og tilværelsesforståelse. Denne understregning er tillige i vor tid fulgt op af flere teologer, der har peget på nødvendigheden af en bedre helligåndsteologi. Således har A. M. Aagaard i sin disputats i 1973 behandlet emnet. Endvidere skal det nævnes, at den karismatiske bevægelse i de senere år har bragt helligåndsteologien frem i søgelyset og gjort en nytænkning nødvendig. I almindelighed har der nemlig været en tendens til at forbigå denne del af 
teologien i største hast, og mange dogmatikfremstillinger affærdiger spørgsmålet med et par kapitler til sidst, - helligåndsteologien kan jo let blive et kontroversielt emne, da den direkte berører vor nutidige tilværelse. Men Grundtvig vovede sig altså ud på det dybe vand og talte om Helligånden, og det er da naturligt for dansk teologi, at man i første omgang vender sig til ham, når man søger oplysning om den sag.

En undersøgelse af Grundtvigs helligåndsteologi er altså velmotiveret; men det viser sig hurtigt, at en undersøgelse af alle de mange aspekter, som den rummer, er umulig indenfor de her anviste rammer. Derfor må jeg begrænse undersøgelsens område. Først vil jeg undersøge Grundtvigs treenighedsforståelse, idet hans forståelse af Helligåndens person fremgår af denne. Dernæst vil jeg undersøge Åndens gerning i den treenige Guds virksomhed i verdens historie.

Undersøgelsens grundlag er Grundtvigs Sangvark, Den Christelige Børnelardom, artiklen "Tre-Enigheden« fra Søndagsbogen bind III og endelig prædikener fra perioden 1832 til 1861, hvor først og fremmest alle trykte og utrykte prædikener til 4. og 6. s.e. påske og 1. og 2. pinsedag danner grundlag. Andre prædikener og anden litteratur i øvrigt er brugt efter et mere tilfældigt udvalg.

\section{Udviklingen af Grundtvigs helligåndsteologi}

Som grundlag for den planlagte undersøgelse bruger jeg altså litteratur fra 1831 (da bd. III af Søndagsbogen blev skrevet) til 1861. Denne litteratur bruger jeg ud fra den antagelse, at Grundtvigs helligåndsteologi lå fast $\mathrm{i}$ denne tid. Denne antagelse vil jeg indledningsvis begrunde ved kort at beskrive Grundtvigs udvikling.

I Grundtvigs rationalistiske periode var han skeptisk både overfor talen om treenigheden og overfor talen om en personlig Helligånd. Herom vidner dagbogsoptegnelsen fra 1804 - den 23. juni, hvor talen om disse emner kaldes "den sunde Fornufts Antipode" (VU, I, s. 44).

Påvirkningen fra romantikken og omvendelsen til "gammeldags kristendom" gav ham imidlertid et andet forhold til de gamles overleveringer, idet han nu blev deres talsmand. De første år talte han nu ikke meget om Ånden, og i dimisprædikenen blev Ånden kun lige nævnt i forbifarten. Men fra 1813 nævnes Ånden hyppigere, hvilket får Kaj Thaning til i sin disputats at bemærke, at fra 1813 
»ledsages hvert nybrud i Grundtvigs antropologiske erkendelse af ny proklamation af tro på Helligånden « (Menneske først..., s. 21).

Fra 1814 foreligger der flere vidnesbyrd om, at Grundtvig har arbejdet med spørgsmålene om treenigheden og om Helligåndens personlighed. Prædikenen på pinsedag taler om Helligåndens selvstændighed og om, at man ikke må forveksle Ånden med hans virkning. Fra samme år foreligger der forskellige opgør med Schellings treenighedslære, som Grundtvig på den ene side bekæmper, da den efter hans mening ender i panteisme, men som han på den anden side også lærer meget af, idet han lærer at se velvilligt på treenighedslæren og at hævde Åndens selvstændighed (C. I. Scharling: Grundtvig og Romantikken, Kbh. 1947, side 176). Hermed kan man faktisk i 1814 finde de allerfleste af de elementer, som i en sum kom til at udgøre Grundtvigs færdige treenigheds- og helligåndsteologi. Alligevel kan man ikke sige, at udviklingen er færdig, da der endnu mangler fuld klarhed over mange ting.

I slutningen af 1823 begynder talen om Helligånden at gøre sig gældende på en ny måde, og i foråret 1824 udmønter den sig i digtet "De Levendes Land", som afspejler en øget forståelse for Helligåndens nærvær. Alligevel er det først med den mageløse opdagelse i 1825 , at Helligåndens nærvær helt konsekvent knyttes sammen med sakramenterne og menigheden, og at en autoritet i spørgsmålet om treenigheden findes ved dåben og ikke i Bibelen. Den mageløse opdagelse betegner derfor det mest markante nybrud i Grundtvigs treenigheds- og helligåndsteologi. Efter 1825 kan man finde eksempler på, at Grundtvig nu ud fra sin nye position kan forfægte treenighedslæren og prædike om Helligånden, sådan som det sker i Theologisk Maanedsskrift fra 1826.

I de følgende år konsoliderer Grundtvigs teologi sig. I denne konsolideringsproces bliver det klart for ham, at han må skelne mellem den guddommelige Ånd, som er Guds, og den skabte ånd, som er menneskers. Hermed kan han anlægge et mere positivt syn på den verden, der er udenfor kirken, idet den ikke frakendes enhver gnist af ånd. Fra 1832 skelner Grundtvig således mellem "aand" og "Aand ", hvilket Kaj Thaning har redegjort for i sin disputats.

Således standser denne beskrivelse af Grundtvigs udvikling ved årstallet 1832 . Men da min antagelse var, at man allerede i $1831 \mathrm{kan}$ anse udviklingen for afsluttet, må jeg forsvare min antagelse yderli- 
gere. Dette gør jeg ved at sammenligne artiklen »Tre-Enigheden« i Søndagsbogen bd. III med artiklen "Den Guddommelige TreEnighed « i Den Christelige Børnelardom (VU, VI, s 144 ff.). Denne sammenligning viser en påfaldende lighed mellem tankegangene og argumentationerne i de to artikler, og trods små forskelligheder vidner den om, at Grundtvigs treenigheds- og helligåndsforståelse er tilstrækkelig fast allerede fra 1831.

\section{Grundtvigs treenighedsforståelse og Helligåndens person}

\section{Autoritetsspørgsmålet}

Når Grundtvig udtaler sig om treenigheden sker det på grundlag af de ord ved dåben, som han kalder Herrens egne »Munds-Ord«. Det er først og fremmest den apostolske trosbekendelse, der udtrykker, at der er tre guddommelige personer, men også døbeordene: "I Faderens og Sønnens og den Helligånds navn« udtrykker dette.

Denne stillingtagen til det dogmatiske autoritetsspørgsmål er jo et udtryk for Grundtvigs "Kirkelige Anskuelse«, og den hævdes i modsætning til den lutherske ortodoksi, som ville finde treenighedslæren i Bibelen. Ortodoksiens bibelgrundvold var nemlig blevet rokket, idet dens bevissted for treenighedslæren i Bibelen var blevet afsløret som en sen tilføjelse. I middelalderen var der gjort den tilføjelse til 1. Johs. 5,7, at der er tre, "som vidner i Himmelen: Faderen, Ordet og den Hellig-Aand, og disse Tre ere Eet«. Dette skriftsted havde de luthersk-ortodokse teologer brugt som bevis for treenighedslæren, men da dets sene herkomst blev kendt, og da der i bibeludgaven i 1817 blev tilføjet, at stedet ikke fandtes i håndskrifter, gamle oversættelser eller hos kirkefædrene, blev det uanvendeligt som bevissted. Bl.a. derfor var man på Grundtvigs tid ved helt at opgive treenighedslæren.

I denne situation kommer Grundtvig med sin »Kirkelige Anskuelse« og hævder, at læren om treenigheden ikke skal søges i Bibelen, men i ordene ved dåben "af Herrens egen Mund». 


\section{Treenighedsforståelsen}

I Grundtvigs forståelse af treenighedens indre forhold er det bemærkelsesværdigt, at han hele tiden tager udgangspunkt $i$, at der er tre guddommelige personer, og derved kommer han til at betone treheden fremfor enheden. Hvor en vesterlandsk teolog almindeligvis siger, at der er én Gud, der åbenbarer sig i de tre personer, dær siger Grundtvig, at der er tre guddommelige personer, der i grunden er ét. Allerede ved sin skrivemåde: "Tre-Enighed " peger han på, at sagen drejer sig om tre, der i grunden er enige.

I Søndagsbogen udtrykker Grundtvig direkte sin opposition mod visse "Skriftkloges« udtalelser, og uden tvivl er det de vesterlandske teologer, han opponerer imod:

"har nogen af de Skrift-K loge fortalet eller forskrevet sig, som om vi troede, der var baade tre Guder og dog kun een Gud, det blive deres Sag, men naar vi kalde Gud den Tre-Enige, da mene vi kun, som i det mindste nu skrevet staaer hos Apostelen Johannes, at der er tre Vidner i Guddommen, og at disse Tre ere Eet, hvad jo er noget ganske Andet, end om vi sagde, at tre Vidner som vidne Eet og det Samme, ei blot gjorde eet og gav eet Vidnesbyrd, men var ogsaa kun eet Vidne» (SB, III, side 279).

Grundtvig er sig således bevidst, at han står overfor en tradition, som har betonet enheden i guddommen. I den samme artikel kaldes treenigheden det "guddommelige Fællesskab" mellem de tre guddommelige personer: Fader, Søn og Helligånd; dette udtryk betoner ligeledes treheden fremfor enheden. I Den Christelige Børnelaerdom finder man den samme front, idet Grundtvig siger, at de lærde ofte har skrevet om enheden, så menighedens forestillinger om treheden måtte blive forvirrede, og så at fjenderne i denne tale fandt en klar modsigelse.

I forbindelse med dette spørgsmål må man undersøge, hvad Grundtvig forstår ved det, som han kalder en person. Når han i Den Christelige Børnelaerdom skal tale om, at djævelen er "virkelig til«, mener han, at denne eksisterer som en virkelig fader til løgnen, "som veed af sig selv at sige, er sig selv bevidst som Grund-Løgneren «(VU, VI, side 23). I samme sammenhæng sidestilles "aandelige Bevidstheder" med »aandelige Personer«. En person er her tilsyne- 
ladende en bevidsthed, og det vil igen sige én, der ved af sig selv at sige som et eller andet.

På en tilsvarende måde taler Grundtvig om Helligåndens person: han er en "guddommelig Person, det vil sige: den Høiestes Kraft, som veed af sig selv at sige og uddeler til Enhver eftersom han vil, altsaa er paa guddommelig Maade selvstaendig og fri« (sst., side 44). Her møder vi altså igen udtrykket "at vide af sig selv at sige» som en betegnelse for, at der er tale om en person, og dette udtryk bliver sammen med udtrykket selvbevidsthed karakteristikken af en person. I Dannevirketiden bruger han udtrykket: at have en erfaring af sig selv på sig selv, og dette udtrykker den samme sag, nemlig den, at man sprogligt kan udtrykke sig selv og således transcendere sig selv. I sin redegørelse for gudbilledlighedsbegrebet hos Grundtvig kommer Erik Krebs Jensen (side 69) til det samme svar på spørgsmålet, idet det gudbilledlige hos mennesket, og det må vel igen være det mest personlige, udtrykkes: at modtage indtryk på hjertet og give det udtryk med tungen i "genlydsordet«. Altså kan en person transcendere sig selv i et "jeg", der kan udtrykke bevidsthed om sig selv og desuden være subjekt for viljesverber. Hertil kommer, at en guddommelig person må have guddommelige egenskaber og altså have magt og frihed til at gøre, som han vil.

Det kan således konstateres, at Grundtvig bruger sit normale personlighedsbegreb i sin treenighedsteologi, hvor det ellers er almindeligt at bruge et afsvækket begreb, således som f.eks. Regin Prenter gør i Skabelse og Genløsning (2. udg., Kbh. 1971, s. 38), hvor han fastslår at "person« $\mathrm{i}$ treenighedslæren betyder mere end "rolle«, men mindre end "personlighed " og "selvstændig individualitet«.

I sine betragtninger af treenigheden begynder Grundtvig altså med at slå fast, at der er tre guddommelige personer: Fader, Søn og Helligånd, og disse personer er hver for sig selvstændige og frie. Men heroverfor må man vel stille spørgsmålet om, hvori enheden da består. I denne forbindelse siger Grundtvig i sin prædiken 5.s.e. påske 1851, side 1 :

"alle Christne maae dog tro paa Faderen og Sønnen og den Helligaand, som tre Medvidner i det samme guddommelige Raad og fælles om det samme guddommelige Væsen, og naar man kalder det umueligt at de Tre kan være eet, da glemmer 
man aabenbar, at her ikke er Tale om nogen udvortes, men om en indvortes Eenhed....".

Enheden i guddommen består således i, at personerne er medvidner i det samme råd, og at de er fælles om det samme guddomsvæen, og det kan bemærkes, at der er tale om en indvortes enhed. Formodentligt må denne udtalelse nærmere forstås sådan, at de tre personer er forenet i deres vidnesbyrd om det samme guddomsliv og den samme guddommelige kærlighed, som skal skabe og fuldende verdens historie. Guddomsvæsenet, som de er fælles om, opfatter Grundtvig tilsyneladende ret ukompliceret som en parallel til menneskets væsen. Således prædiker han 2. pinsedag 1833, at ligesom millioner af mennesker kan være fælles om ét menneskeligt væsen, således kan vel også tre guddommelige personer være fælles om det samme guddomsvæsen. Denne tankegang udtrykker han i verset:

Da Menneske-Naturen godt

Kan rumme Millioner, For den Guddommelige smaat

Maa synes tre Personer,

\section{152,3}

Der er altså tale om en slags guddomsnatur, som de tre personer har på hver sin måde. De åbenbarer det samme guddommelige råd og væsen, idet Faderen åbenbarer det som fader, Sønnen som søn og Ånden som ånd.

Enheden kan beskrives som kærlighedens enhed. Således siger Grundtvig f.eks.:

„Faderen og Sønnen og den Helligaand, der er langt fuldkomnere eet i Kiærlighed end selv de kiærligste Ægtefolk kan blive herneden, de er sig, hver efter sit Navn, Guddoms-Livet bevidst $\mathrm{i}$ hele dets evige Fylde, saa hver har sin Maade at bruge og aabenbare det paa..." (5. s.e.påske 1851, side 3.)

Kærligheden forener her de tre personer, ligesom den kan forene ægtefæller; forbundne i kærlighed er de tre personer hver især sig selv den samme guddomsnatur bevidste. Imidlertid vægrer man sig uvilkårligt ved at sætte et lighedstegn mellem guddomsvæsen og kærlighed, idet væsen for os fører tanken hen på noget materielt; 
men da Gud er åndelig, kan Grundtvig godt sige, at hans væsen er kærlighed, idet man her må huske, at kærligheden for ham er den kilde, hvorfra alt andet flyder: livet, sandheden, lyset, styrken osv.. Det er disse guddommelige kræfter, som vi kender, fordi de giver navn til Ånden: Råds og styrkes Ånd, kærligheds og sandheds Ånd, lysets og livets Ånd m.v.; alle disse kræfter har deres rod i kærligheden. Fremdeles er det disse guddomskræfter, som mennesker får del $\mathrm{i}$ ved Ordet og Ånden, så menigheden kan synge de kendte linjer: "Fælles om hans Liv og Fred, Lys og Kraft og Herlighed" (DDS 333). Ligesom Jesus havde del i Faderens væsen, således skal også menigheden have del i den.

Med denne opfattelse af enheden og treheden i treenigheden har Grundtvig bevæget sig bort fra den traditionelle vesterlandske teologi, hvor enheden betones meget stærkere. Således kan man til sammenligning læse, hvorledes Prenter i Skabelse og Genløsning (side 47) betoner, at det er én og samme Gud, der kaldes med de tre navne, og når Prenter skriver (side 51), at Gud kan »tænkes abstrakt som et almenbegreb, "guddommelighed «. De tre personer er da selvstændige individer, som alle har del i samme egenskab "guddommelighed «. Dette er tritheisme...«, kan man føle, at Grundtvig nærmer sig denne »tritheisme«. Men er han tritheist, må man vel så spørge!

I forbindelse med dette spørgsmål om tritheisme er det rimeligt at anføre, at Grundtvig ikke gør sig til talsmand for en streng monotheisme:

"de Christnes Guddom, der hverken som Hedningernes er en Vrimmel af mangfoldige, selvgjorte Guder, eller som Mahomeds en enkelt sønneløs og aandløs, ukiendelig og livløs, umuelig og selvmodsigende Gud-Fader, men er en hellig Treenighed " (trinitatis søndag 1833, side 2).

Ganske roligt placerer Grundtvig i denne prædiken kristendommens gudsopfattelse et sted mellem den strenge monotheisme og polytheismen, og når han $\mathrm{i}$ Den Christelige Børnelardom skal forsvare sig overfor beskyldninger for tritheisme, forsvarer han sig ikke ved at reducere personernes selvstændighed, men løser problemet ved at lade Sønnen og Ånden være underordnet Faderen, så Faderen bliver udtryk og garant for enheden i guddommen. Denne Faderens overordning - monarki - finder Grundtvig i 1. Kor. 8.6, hvor Paulus skriver, at der er én Gud, Faderen, af hvem alle ting er; 
men Grundtvig er udmærket klar over, at han ikke er i overensstemmelse med den lutherske ortodoksi, når han hævder denne overordning, for han bemærker, at han ved, at de såkaldte "snorrette (orthodoxe)« teologer ville korse sig ved denne tankegng(VU, VI, side 147). Alligevel fastholder Grundtvig overordningen, idet han hævder, at der ikke kan være to sideordnede og uafhængige guddomsbærere, da dette er en selvmodsigelse. Imidlertid er der kun tale om en under- og overordning i henseende til afhængighed. Faderen er nemlig den eneste, der eksisterer ved sig selv og af sig selv. Både Sønnen og Ånden har deres eksistens af og ved Faderen, selv om de ellers er lige med ham $i$ alt og evige som han.

\section{De tre guddommelige personer}

Når man vil forsøge at finde ud af, hvordan Grundtvig beskriver de guddommelige personers særegenheder og deres indbyrdes forhold, må man først og fremmest bemærke den overmåde store betydning, som Grundtvig tillægger deres navne: Fader, Søn og Ånd. Det, som her gør sig gældende, er Grundtvigs forståelse af, at de himmelske og guddommelige ting og fænomener ikke kan udtrykkes i en logisk, diskursiv sprogbrug, men kun kan formidles ved billeder (jvf. side 193). Det ville efter Grundtvigs tankegang være fejlagtigt at tro, at man ved en længere forklaring kan trænge ind bag det, som billedet udtrykker. Kun ved at trænge til bunds i, hvad et fader-søn-forhold er, kan man begribe Faderens og Sønnens indbyrdes forhold:

»1. Cor.XV, 25-28, som man heraf seer, er i Apostel-Skolen forklaret ligefrem, uden alle dogmatiske Spidsfindigheder, saa det var først de senere Skriftkloge, der, da Arianerne misbrugde Sproget, lod sig forlede til at gjøre Vold paa det! Sagen er yderst simpel, naar man blot har en levende Tro paa Faderligheden og Barnligheden, som et virkeligt levende Forhold $\mathrm{i}$ Guddommen, og har man ikke det, men vil dog gruble over Tre-Enigheden, da kommer der altid en Umuelighed ud, som gjør Tro og Bibel Skam, skjøndt de er himmelsk uskyldige» (Irenæusoversættelsen, Kbh. 1855, side 128).

Altså skriver Grundtvig således i en kommentar til Irenæus, og herved afviser han de forsøg, der er gjort på ved hjælp af filosofien at redegøre for de trinitariske forhold. Denne forståelse af billed- 
sproget kommer til udtryk fra midt i 1820 'erne, og fra den tid finder man ikke mere spekulative udredninger om treenigheden som dem, han kom med i 1814 i opgøret med Schelling.

Faderen omtales i overensstemmelse med dette først og fremmest som den, af hvem al faderlighed i Himmelen og på jorden bærer navn. I faderligheden ligger, at de to andre personer har deres oprindelse fra ham, og derfor kaldes han guddomshjertet og guddomsdybet, hvorfra Sønnen og Ånden udgår med guddomslivet. Han er den for os ubegribelige, usynlige og skjulte kilde og rod til hele livet.

Sønnens særegenhed er evigt at være søn. Han modtager altså sin eksistens fra Faderen, men er ellers hans udtrykte billede og lige med ham i magt og guddomsherlighed. Sønnen er ligeså evig som Faderen, for hvis Sønnen ikke var evig søn, var Faderen ikke evig fader, men Gud må nødvendigvis evigt være, hvad han er. Med dette sidste ræsonnement afgrænser Grundtvig sig overfor arianismen, og denne afgrænsning gør han i øvrigt meget ud af, idet han understreger, at Sønnens underordning under Faderen kun drejer sig om den underordning, som sønnenavnet udtrykker. Subordinationen har kun til hensigt at hævde Faderens monarki, idet Sønnen ellers er lige med Faderen og har fået givet "at have Livet $i$ sig selv" ligesom Faderen og skal æres lige med ham. Han er desuden selvstændig og fri, så han kan give livet til »hvem han vil«. Endvidere afgrænser Grundtvig sig overfor dem, der nok kalder Jesus Guds Søn, men gør det ud fra den forståelse, at alle mennesker er Guds sønner. Denne væsensforskel mellem Jesus, der i evighed er Guds Søn, og alle dem, der i ham er Guds børn, hævder Grundtvig ved at betone ordet "énbåren".

Sønnen benævnes endvidere som Guds Ord. Guds Ord udtrykker Faderens væsen i en form, som mennesker kan begribe og modtage. Dette gælder, både når han fremtræder som skaberordet, det inkarnerede ord, og som ordet ved sakramenterne.

Helligåndens person er jo det egentlige emne for denne undersøgelse, og derfor skal han i særlig grad omtales.

Først og fremmest må det bemærkes, at Helligånden i evighed udgår fra Faderen. Det stærkt omstridte »filioque« (d.v.s. ordene "og fra Sønnen« i den nikænokonstantinopolitanske trosbekendel- 
se) findes ikke hos Grundtvig i den vesterlandske tolkning, der siger, at Helligånden i evighed udgår fra Faderen og fra Sønnen og er deres indbyrdes kærlighed - nexus amoris (kærligheds bånd). F.eks. siger Grundtvig:

"thi Han som haver skiænket os sin elskelige Søn, skulde Han ikke skiænke os alle Ting... for at Aanden, som ret egentlig udgaaer fra Ham, den Hellig-Aand kunde igien komme i fuld Virksomhed som Trøster, Talsmand og Veileder til al Sandhed hos det Folk, som Hans eenbaarne Søn kiøbde med sit Blod og forsikkrede paa sin Guddoms-Ære, at Han vilde sende dem Fader-Aanden til en evig Trøster" (pinsedag 1834, side 5f.).

Her siger Grundtvig direkte, at Helligånden "ret egentlig« udgår fra Faderen, men på grund af forsoningen kan Jesus sende os Ånden. Det er tilsyneladende Johs. 15,26, der spiller en afgørende rolle for Grundtvigs tankegang; her siger Jesus, at han vil sende Faderens Ånd. Påvirket af Bibelen og af den østerlandske kirke bryder Grundtvig med traditionens filioque-forståelse, og i prædikener og salmer finder man en mængde eksempler på, at Helligånden er Faderens Ånd.

I denne forbindelse skal det også nævnes, at Grundtvig ikke identificerer Helligånden med "nexus amoris" - kærlighedsbåndet mellem Faderen og Sønnen. Som allerede nævnt hører kærligheden hos Grundtvig til det fælles guddomsvæsen, og hvis den tillægges en bestemt person, er det Faderens, idet dén ene skal vare ved og ene kan eksistere ved og af sig selv.

Men selv om Grundtvig ikke bifalder den almindelige tolkning af "filioque«, kan han dog tale om, at Helligånden både går ud fra Faderen og Sønnen. Men meningen med denne tale er, at Ånden var Jesu Ånd og kom til jorden på en ny måde med ham og går nu ud i hans navn til Kirken. Vi kender altså Faderens Ånd som Sønnens Ånd og kan kun søge Ånden hos Sønnen, hvor han kan kendes og findes. Men Ånden er dog Faderens Ånd, som Sønnen har, fordi alt Faderens er Sønnens. Det er Faderen og ikke Sønnen, der er Åndens rod og kilde. På denne måde siger Grundtvig hverken "og fra Sønnen« i gængs forstand eller "fra Faderen alene» (ek patrou monou), som den græske tradition har sagt i opposition til "filioque«. Ånden udgår fra Faderen ved Sønnen. 
I en redegørelse for Grundtvigs teologi om Helligåndens person er det vigtigt at gøre opmærksom på dens betoning af, at Ånden er en selvstændig personlighed. Således skriver han:

"Ligesom vi nu, ved at udlede den christelige Treenigheds-

Tanke udelukkende af Menighedens Fællesbekiendelse og Daabs-Ordet, undgaaer al Selv-Modsigelse og alt Kiætteri om Sønnen, saaledes undgaaer vi ogsaa derved den Grund-Vildfarelse om den Helligaand, at der egenlig ingen Helligaand skulde være til, men kun en Slags hellig Aande, sig selv ligesaa ubevidst som vores Aande" (VU, VI, side 148).

Der har i den vesterlandske teologi været en tilbøjelighed til at betragte Helligånden som en upersonlig kraft. Denne tilbøjelighed, som i nogen grad er en følge af filioque-forståelsen, kæmper Grundtvig hele livet imod. Helligånden må ikke forveksles med sin virkning, sagde Grundtvig allerede i 1814, og gang på gang skælder han ud over, at Helligånden ikke bliver omtalt som »han «, men at man vil snyde sig fra det med et "den", "der lader ham svæve mellem Himmel og Jord i det Ubestemte, og da egenlig i Luften..." (pinsedag 1832, side 8). Denne strid er siden blevet fortsat, idet man i trediverne havde en strid om, hvorvidt der kunne tilføjes et $e$ i trosbekendelsen, så ordlyden blev, at vi tror på den hellige Ånd; denne strid om "det lille e» viser, hvor tungt det ligger i dansk teologi med at anerkende Åndens personlighed.

Det er allerede omtalt, at personlighed for Grundtvig betyder et selvstændigt, selvbevidst "jeg". Helligånden er ikke en upersonlig kraft. Han kan sige: "jeg er«, og som en guddommelig person kan han gøre, som han vil, selv om han i guddommelig ydmyghed ikke taler af sig selv, men tager af Sønnens og forkynder videre. Uenighed mellem de guddommelige personer, hvis væsen er kærlighed og sandhed, kan selvfølgelig ikke tænkes.

Sønnen og Helligånden udgår således begge fra Faderen som to lige evige og selvstændige personer, der ind ordner sig under hinanden og følger hinanden. Således bliver Sønnen og Ånden hinandens ligemænd, og de er hver for sig underordnet Faderen. Derfor kan Grundtvig bruge det gamle billede, som bl.a. Irenæus bruger, hvor Sønnen og Ånden sammenlignes med Guds hænder: 
Dine Hænder, sang de Ældste, Er Din Søn og Helligaand,

\section{385,7}

Med dette billede udtrykkes parallelliteten mellem Sønnen og Ånden.

I tilknytning til disse tanker om Sønnens og Åndens indbyrdes forhold skal det også nævnes, at identifikationen af Guds Ord og Kristus er nært knyttet til dette forhold. I selve Grundtvigs åndsforståelse ligger nemlig, at en ånd er en kraft, der kun kan legemliggøres i ord. Både folkeånd og Helligånd må udmøntes i ord, for at de kan have nogen eksistens. Det er tanker, som Grundtvig allerede arbejder med i Dannevirketiden, og de fastholdes hele livet: „Og Lyd er kun Legem for Aanden" (I 194,4); »Og Ordet af Vorherres Mund..., Det er Guds-Aandens Sæde« (IV 300,1). Derfor kan Grundtvig også sige, at "Aandens Kraft er Ordets Marv«, og at "Aanden er, hvad den selv kan virke, Aand er Ordet i sin Kraft $\lll$. Ligesom Sønnen og Ånden er uadskillelige, sådan kan Ordet og Anden heller ikke være uden hinanden:

"Ja, Aanden er Tungernes eller Ordets Livskraft, saa Ord uden Aand er Hverdagstale, men Aand uden Ord er tom Ind bildning" (2. pinsedag 1839, PF, side 533).

I det hele taget er det en afgørende betingelse for at forstå, hvad Grundtvig tænker sig vedrørende ånd, at man holder denne nære sammenknytning af ord og ånd fast.

\section{Menneskets muligheder for gudserkendelse}

I det foregående er det beskrevet, hvorledes Grundtvig på flere punkter bryder med den vesterlandske treenighedsforståelse. Ikke blot ved sin betoning af treheden i den treenige guddom bryder han med de latinske og lutherske fædre, men han gør det også ved at skelne imellem, hvorledes de guddommelige personers indbyrdes forhold er, når de betragtes udenfor tid og rum, og når de betragtes i deres fremtræden i verdens historie. Denne skelnen afvises almindeligvis i den vestlige teologi; således finder man hos Regin Prenter en afvisning, der er begrundet med, at en sådan skelnen åbner vejen for mystik og "speculatio majestatis«, og i modsætning dertil hæv- 
des der, at Gud er i evighed den samme som den Gud, der åbenbarer sig i historien (Skabelse og Genløsning, 2. udg., Kbh. 1971, side 50).

Det er imidlertid interessant at stille de to opfattelser op overfor hinanden, thi Grundtvig ville uden tvivl give Prenter ret, når han sagde, at Gud i evighed er den samme som den Gud, der åbenbarer sig i historien. Men Grundtvig ville nok forstå ordene anderledes, idet han i højere grad end Prenter ville se tingene $\mathrm{i}$ et historisk perspektiv. For det første ville menneskets muligheder for at erkende Gud være betinget af historien, og for det andet er historien ikke afsluttet, og derfor er Guds åbenbaringshandlinger heller ikke ophørte endnu. Der må da være en spænding mellem, hvordan Gud nu har åbenbaret sig for os, og hvordan han er, når han er kendt fuldt ud.

Grundtvig mener, at menneskets muligheder for at kende Gud er betinget af historien. Mennesket blev nemlig ikke skabt med en fuld erkendelse af Gud, men blev skabt til at komme til en "levende Tanke om den guddommelige Treenighed og til Oplysning om dens personlige Virksomhed" (VU, VI, side 149). Denne erkendelse skulle ske ved menneskets selvbetragtning og ved Åndens oplysning i løbet af historien, og derfor bliver den afhængig af, hvor langt man er fra historiens mål.

Når mennesket endnu ikke kan erkende dybderne i den treenige guddom, skyldes dette således ikke, at det på forhånd frakendes enhver mulighed for at erkende Gud, fordi det er et begrænset væsen uden nogen mulighed for nogensinde at kunne fatte Guds vældige majestæt. På grund af menneskets skabelse i Guds billede kan det nemlig have "en sand og levende Forestilling om Gud og hans Egenskaber", idet der er "Noget i Mennesket af Alt, hvad der er i Gud" (sst., side 114f.). Fordi Mennesket fra begyndelsen var ligedannet med Gud, kan der gennem ord formidles et kendskab til ham, idet mennesket ved sin taleevne har »en Bekvemhed til at kiende Gud “ (sst.). Når mennesket endnu ikke har fuldt kendskab til treenighedens væsen, skyldes det altså ikke, at Grundtvig vil understrege menneskets intellektuelle uformåenhed, men at mennesket skal nå det fulde kendskab"i tidens løb, fordi kun det guddommelige kan begribe det guddommelige. Gennem historien skal mennesket vokse $\mathrm{i}$ lighed med $\mathrm{Gud} \mathrm{og}$, efterhånden som ligheden bliver større, nå den samme erkendelse, som Gud har af sig selv, og som Sønnen havde af Faderen. Grundtvig ville nok sige, at det 
begrænsede ikke kan rumme det ubegrænsede, men tilføje, at efterhånden som mennesket bliver ubegrænset, kan det begribe det ubegrænsede og kende Gud fuldt ud.

Udviklingsforløbet frem mod den fulde gudserkendelse blev imidlertid afbrudt ved syndefaldet, hvor menneskets begreber blev formørkede og forvirrede. Derfor er det kun ved »en overordentlig Aabenbaring«, og det vil i første omgang sige ved ordene ved dåb og nadver, at det faldne menneske kan få kendskab til den rette orden og følge i treenigheden (sst., side 149f.). Ved genløsningen her bliver mennesket genindsat i sin oprindelige løbebane på vej fremad mod den fulde erkendelse. Derfor kan det genløste menneske heller ikke straks have en fuld viden om treenighedens væsen. Kun gennem den løbebane, som er åbenbaret for os i Kristus, kan erkendelsen nås, og først når vi er ligedannede med Kristus, skal vi erkende fuldt ud.

For den enkelte er tilegnelsen af Guds åbenbaring altså en fortløbende proces; men heller ikke Guds åbenbaringshandlinger er afsluttede. Der sker fortsat en åbenbaring ved Helligåndens virksomhed, og kun ved at se disse spor af den treenige Guds virksomhed i nutiden kan man nå til en dybere erkendelse af Guds væsen, og da sporene i verden er utydelige og forvirrede på grund af synden, må man vende sig til de guddommelige indstiftelser, hvor Gud uforfalsket meddeler sig til mennesker.

Hvor åbenbaringshistorien i den lutherske tradition tilsyneladende er en afsluttet begivenhed, som endte med himmelfarten og pinsen, og som nu kun findes af troen i Bibelen (sola fide, sola scriptura), dær fortsætter åbenbaringshistorien for Grundtvig i kirken, hvor Gud ved dåben og nadveren giver sig til kende for hver enkelt.

Hermed vender Grundtvig blikket væk fra Bibelen og retter det mod nutiden. Han siger:

"Da nu ogsaa de lutherske Lære-Bygninger ligesom de calvinistiske hvilede paa det døde Bogstav og Skrift-Begreb...» (sst., side 80 ).

Hermed mener han, at skriftprincippet i den lutherske kirke har været et fejlgreb, - Gud skal ikke søges i Skrifterne, men i det nærværende. Det er kun "giennem det nye christelige Menneskeliv, vi kan spore Guddommens personlige Virksomhed" (sst., side 149f.). 
Grundtvigs åbenbaringsforståelse bliver således meget dynamisk, da den udtrykker et levende vekselvirkningsforhold mellem en Gud, som stadigvæk åbenbarer sig, og et menneske, som i samfundet med denne Gud vokser i indsigt og i evner til at erkende ham. Det udtrykkes sådan:

"det Guddommelige, som overgaaer Menneske-Begrebet i sig selv, kan umueligt blive os klart uden igiennem en Deeltagelse

i Guddoms-Livet, som bliver sig selv klar...» (sst.).

Kun ved at få del i guddomslivet, og det vil sige at vokse med Kristus, kan man nå til en dybere indsigt i guddomsvæsenet, idet dette guddomsliv kommer til erkendelse af sig selv.

Det er også interessant at iagttage, at der er et skel mellem på den ene side den elementære erkendelse, som gives $i$ dåben, og som derfor er fælles for alle kristne, og på den anden side den fulde indsigt, som fås gennem beskuelsen af Gud ansigt til ansigt.

Dette skel giver en spænding mellem det, som allerede er åbenbaret, og det, som skal blive det. Ved dåben er det allerede åbenbaret, at Gud er Fader, Søn og Helligånd, og at han skal kendes ved Sønnens og Åndens virksomhed. Ved nadveren

\section{Aabenbarer efterhaanden \\ Sig Gud-Fader selv i Aanden, Med sin hele Kiærlighed!}

\section{114,65}

Ved nadverfællesskabet trænger mennesket dybere og dybere ind i erkendelsen af Faderens væsen. Da Faderens væsen jo netop er det fælles og enhedsgivende guddomsvæsen i den treenige guddom, er erkendelsen af enheden $\mathrm{i}$ treenigheden således noget, som skal komme i denne proces. Da Helligånden er den erkendelsesgivende, er det indlysende, at han kommer til at spille en afgørende rolle som den, der ransager dybderne i Gud og formidler denne indsigt videre til mennesker. 


\section{Helligåndens gerning i verden}

Hvor opmærksomheden i det foregående har været rettet mod Grundtvigs treenighedsteologi for at bestemme Helligåndens person i forhold til Faderens og Sønnens personer, skal opmærksomheden i det følgende vendes mod Helligåndens del af den treenige guddoms handlinger i og med verdens og frelsens historie.

Med denne formulering har jeg udtrykt, at det ikke blot drejer sig om at undersøge Åndens gerning som kirkebygger og helliggører. Dette ville nemlig ikke være retfærdigt overfor Grundtvig, da han nok kan karakterisere de guddommelige personer ved deres handlinger (ikke mindst under indflydelse af den apostolske trosbekendelse), men han deler ikke den samlede guddomsgerning op i tre adskilte dele, som hver tilskrives en person. Derimod understreger han, at alle tre personer er med $\mathrm{i}$ alle gerningerne $\mathrm{i}$ verden. Både Ordet og Ånden er med ved skabelsen, og i Sønnens fremtræden virker også Faderen, der siger: »denne er min søn!«, og Ånden, der daler ned som en due. Ligeledes følges Ånden af Sønnen og Faderen, der med ham tager herberge hos mennesker.

Det er altså rimeligt at følge historiens gang og undersøge Åndens funktion i de forskellige afsnit.

\section{Verdens skabelse og tiden efter syndefaldet}

Ved verdens skabelse udgik Helligånden sammen med Guds Ord fra Gud-Fader i det store "skaber-bliv«. Med dette "bliv« kaldtes den ordnede verden frem af kaos:
Men Guds Aand fra Vest til Øst
Svæved i Hans Almagts-Røst
Kaldte Lyset frem af Mørke,
Skabde Paradis af Ørke.

\section{17,1}

Grundtvig tolker 1. Mosebog 1,3 sådan, at »ruah elohim« er Guds Ånd.

Ved Guds Ånd og Ord kaldes livet frem, og derved får hele skaberværket Guds præg: 
Da Gjenlyd af Stemme

Fik Klipper i Giemme,

Som Fuglenes Bryst,

\section{1,32}

I opposition til romantikken afholder Grundtvig sig dog fra at tale meget om Gud i naturen. Guds gerninger sættes snarere ind i en historisk sammenhæng.

I prædikener og salmer, som hovedsageligt udgør grundlaget for denne undersøgelse, beskæftiger Grundtvig sig næsten udelukkende med en verden, der er centreret omkring menneskets fornedrelse og ophøjelse. Derfor kommer menneskets skabelse til at spille en meget dominerende rolle i Grundtvigs fremstilling af skabelsesakten. I fremstillingen af menneskets skabelse anvender han hyppigst forskellige billeder fra Bibelens skabelsesberetninger. Ved disse billeder beskriver han forskellige fænomener, som sammenstykkes til en antropologi. Denne antropologi er i og for sig en nødvendig forudsætning for at kunne forstå Grundtvigs tale om nyskabelsen.

Grundtvig understreger stærkt, at mennesket må vide af sig selv at sige som menneske, før det kan høre Guds røst og tage imod evangeliet, som er $»$ Dyre-Mennesket eller Menneske-Dyret en Daarlighed «. Derfor må man først og fremmest vide, at mennesket er et åndeligt væsen:

Aandepustet fra det Høie Gjorde mig til Jordens Drot, Abekat og Papegøie

Af mig har en Skygge blot:

III 201,1

Andepustet, som nævnes, kommer fra fortællingen om, at Gud tog en klump af agermulden og dannede mennesket deraf og blæste livsånde ind $\mathrm{i}$ ham. Med dette åndepust er der sikkert fulgt en befaling om at blive menneske, således at mennesket ved denne handling fik del i ordenes og åndernes verden. I alt fald får mennesker ved skabelsen evne til at meddele en usynlig verden til hinanden ved ord, og denne evne adskiller mennesket fra alle de umælen- 
de skabninger. Taleevnen giver endvidere mennesket mulighed for at herske over verden, idet han kan give navne til sine erfaringer; derfor spiller denne evne en stor rolle i talen om gudbilledligheden, idet mennesket ved den har mulighed for at tale med væsener af den usynlige, åndelige verden.

I forbindelse med talen om Ånden er det vigtigt at mærke sig, at det hører til gudbilledet hos mennesket, at mennesket har ånd og evne til at meddele den videre ved ord ligesom Gud. Erik Krebs Jensen, der jo har beskæftiget sig med Grundtvigs antropologi, beskriver menneskets gudbilledlighed (side 91) og viser, at hjertet spiller den centrale rolle i det. Ud fra de erfaringer, som i det foregående afsnit om treenigheden er kommet frem, er det imidlertid rimeligt at pege på, at Grundtvig i 1814 ser gudbilledet som et billede af treenigheden, og at man derfor kan drage paralleller. Hjertet er da det gådefulde dyb, der skal forklares, og ordet og ånden afspejler dette dyb ved de udtryk, som de formidler, og de påvirker ligeledes hjertet ved indtrykkene, som de formidler.

Vigtigheden i denne forbindelse er at fastslå, at mennesket ved skabelsen får tildelt en barnelod af Guds egen Ånd, og denne lod skal gennem historiens udvikling vokse op i samfund med Guds Ånd og blive fuldstændig ligedannet med ham. Ligesom menneskeordet er en genlyd af Guds Ord, må menneskeånden være en ånd i lighed med Helligånden. Ofte kan det nemlig se ud, som om Guds Ord og Guds And umiddelbart inkarnerer sig hos mennesker, men så viser det sig andre steder, at Grundtvig opretholder en ontologisk forskel mellem skaberen og det skabte. Således siger han, at når Paulus taler om legeme, sjæl og ånd, så ville nogle måske mene, at det kun drejede sig om kristne, som havde Helligånden, "men da vi hos den samme Apostel finder det udtrykkeligt sagt, at Guds Aand vidner med vor Aand, at vi er Guds Børn, saa kan vi ikke tvivle om, at han jo taler om en virkelig Menneske-Aand, der er Noget Andet end Sjælen..." (5. december 1866, side 2). Det er inkarnationens hemmelighed, der gør sig gældende, og da den netop er en hemmelighed, kan det forsvares, at Grundtvig taler så utydeligt om dette forhotd. Når han siger: "Men kun hos os med Aand og Ord/Sig selv Han skabde Huus paa Jord«(V 5,1), har han i alt fald gjort opmærksom på, at inkarnationstanken her har indflydelse. Netop ved menneskets ord og ånd har Gud mulighed for at inkarnere sig. 
Mennesket bliver altså skabt med en ånd, der ligner Guds, og denne ånd skal i samfundet med Guds Ånd vokse op til sin skabers lighed. Ved skabelsen var mennesket, som det allerede tidligere er nævnt, bestemt til at gennemløbe en historie og komme til klarhed over sig selv, idet det var sig selv en gåde og var som den eneste skabning bestemt til at forklares.

Menneskets forklaring forstår Grundtvig ud fra sin tredeling af mennesket i legeme, sjæl og ånd. Sjælen er det egentlige "jeg» selvet. Mennesket var således bestemt til, at sjælen tjente ånden og beherskede legemet, så kødet blev åndeliggjort og blevåndens klare redskab og udtryk. Ved syndefaldet blev mennesket skilt fra "Sandhedens Aand «, og derved blev menneskeånden magtesløs, og sjælen kom i legemets vold. Denne adskillelse af sjæl og ånd kaldes åndelig død, hvor legemlig død er adskillelse af sjæl og legeme, belærer Grundtvig menigheden om på 6. s. e. påske 1849, side $2 \mathrm{ff}$.

I forbindelse med talen om menneskeånden er der imidlertid en interessant og vigtig iagttagelse fra 5 . december 1866 , hvor han i sin prædiken siger, at ånd ikke er en kvalitet ved det enkelte menneske, men er noget kollektivt, som hører til i et fællesskab af åndelige væsener:

Tilhørerne må ikke tro, "at hvert Menneske-Barn, som har en Sjæl og et Legeme for sig selv, skulde ogsaa have en Aand for sig selv, " men at »Menneske-Livet er ikke fuldstændigt uden at have en Aand, som er en Livskraft med Ordet i sin Magt. Herved er nemlig vel at mærke, at ligesom det er med den Helligaand, at vi kun kan have ham tilfælleds med alle vore Medchristne, saaledes er det ogsaa een og den samme Menneske-Aand i hvem alle Mennesker kan og skal have Deel, saa at hvor den fattes er det en Følge af Syndefaldet..." (side 3).

Selv om Grundtvig ikke selv taler konsekvent ud fra denne kollektivtanke, er det dog værd at lægge mærke til, at den forekommer. Kollektivtanken fastholder i høj grad, hvor betinget mennesket er af sine omgivelser, og hvordan der er et spil mellem individ og samfund.

Syndefaldet gjorde imidlertid en ende på den harmoniske udvikling frem mod alle tings mål. Ved syndefaldet blev menneskeånden skilt fra Guds Ånd, og derfor blev den magtesløs, og menneskesjælen måtte krybe omkring i støvet. Sjælen, som var bestemt til at være alle de skabte tings herre, kom i elementernes vold, og mennesket 
blev underlagt forkrænkeligheden, og døden fik magt over livet.

Ved syndefaldet blev menneskets gudbillede ødelagt. Øret blev døvt for Guds kald, øjet blindt og tungen mistede evnen til at tale med liv og ånd. For Grundt vig er Syndefaldet en afgørende realitet, som virkelig sætter skel mellem mennesket og dets skaber, og som modsiger al romantikkens udviklingsoptimisme. Imidlertid hævder han ikke, at gudbilledet fuldstændigt blev tabt ved syndefaldet, for så ville mennesket jo ikke længere være et menneske. Mennesket må have bevaret et minde om, at dets hjerte i grunden var skabt i lighed med Guds, og dette minde ytrer sig i et suk. Dette er udtrykket for, at mennesket også har en rest af ånd, som bevirker, at de ord, der er knyttet hertil, ikke blot er tomme lyde. En vis indskrift af Sandhedens Ånd i hjertet, som kaldes samvittigheden, giver stadigvæk mennesket en vis evne til at skelne mellem sandhed og løgn, selv om evnen er begrænset.

For Åndens vedkommende må det altså konstateres her, at ved syndefaldet blev menneskets ånd skilt fra sin skaber, og derfor sank den hen i magtesløshed. I Israels folk fortsatte Gud dog sin vandring med menneskeslægten, idet Gud specielt udvalgte sig dette folk. På trods af alle sine universalistiske tanker fastholder Grundtvig dette folks særstilling som et særligt sted for Guds åbenbaring. Hos Israels folk virker Ånden gennem forskellige udvalgte mænd og kvinder. Grundtvig nævner således i forbindelse med omtalen af profeterne og andre markante personer i Det Gamle Testamente, at de blev drevet af Ånden. Det gælder f.eks. Gideon, Debora, Saul, David, Salomon, Ezekias, Esajas osv. Grundtvig må selvfølgeligt skelne mellem den gamle og den nye pagts folk, men det er vanskeligt at finde en helt fast skillelinje. F.eks. kan forskellen karakteriseres ved, at i Israel var Ånden først og fremmest til stede som sandhedens Ånd, hvor han i kirken i første række kaldes kærlighedens Ånd. Det afgørende skel er uden tvivl forsoningen, men det kan også betones, at først efter pinsedagen tager Ånden virkelig bolig blandt mennesker; således siger Grundtvig 6. s.e. påske 1849, side 8, at Ånden som en fugl svævede over issen på folk, indtil han med pinsebegivenheden tog bolig i dem.

De andre folkeslags forhold til Helligånden er ikke så umiddelbart som Israels. Hvert folk har sin folkeånd, som lever i og med modersmålet, og som gives videre fra slægt til slægt i myter, sagn og overleveringer; men disse folkeånder er forskellige fra Helligånden, 
så derfor må en undersøgelse af disse folks forhold til Helligånden indebære en undersøgelse af, hvorledes det indbyrdes forhold er mellem folkeånd og Helligånd.

Allerede af den positive omtale, Grundtvig giver folkeånderne, fremgår det, at der ikke kan være nogen direkte modstrid mellem et folks gode ånd og Helligånden. På et vennemøde i 1865 kan Grundtvig sige, at "Nordens Aand har saamegen Lighed med Guds egen Aand, at den har sit Øie fæstet paa den store Kamp«, og han kan sige, at Nordens Ånd styrker "Lysets Rige» mod "Hel«, og Nordens Ånd kan endog personificeres som en engel, der følger dens folk.

Alligevel identificerer Grundtvig ikke Nordens Ånd og Helligånden. Der er en ontologisk forskel mellem skaber og skabning. I Nordens Mytologi 1832 siger han (VU, IV, side 72), at »Christendommens Kampe-Aand er den Eneste, der fortjener GuddomsNavn og Tilbedelse«, men han tilføjer, at derfor er Nordens Ånd både uundværlig og berettiget til beundring.

Der er altså både en forskel og en sammenhæng mellem folkeånderne og Helligånden; men Grundtvig er ret påholdende med at oplyse noget om den nærmere forbindelse. Men det er formodentligt korrekt at sige, at menneskeånden, som allerede i det foregående er omtalt, har udmøntet sig i forskellige folkeånder, der hver har deres udtryk i de forskellige tungemål. Det hører altså med til overvindelsen af synden, at disse folkeånder i tidens løb forklares og sammensmelter, således at de på Vorherres Jesu Kristi dag er forklaret i og sammensmeltet med Helligånden.

I denne sammenhæng skal det også fremdrages, hvorledes Grundtvig understreger, at kun ud fra en forståelse af, hvad ånd og folkeånder er, kan man forstå noget af, hvad der menes, når der tales om Helligånden. Kun når man har en erfaring af den virkelighed i verden, der benævnes med ordet ånd, kan man forstå kirkens tale om Guds Ånd.

\section{Helligåndens virksomhed i Jesu liv og gerning}

I det foregående er der redegjort for, hvorledes menneskeånden og folkeånderne er virkninger af Helligånden i den skabte verden. Disse er nødvendige forudsætninger for, at verden kan genløses, og for at målet med skabelsen kan nås. I det følgende skal det undersø- 
ges, hvorledes Helligånden først virker i Jesu liv og gerning, hvorefter han begynder en ny virksomhed på pinsedagen, som ret egentlig er hans egen.

I forbindelse med Jesu fremtræden for Israels folk skal det først nævnes, at Grund tvig lægger en del vægt på ordene: "undfanget ved Helligånden « i den apostolske trosbekendelse. Med disse ord understreges ikke blot Jesu guddommelighed, men også at han ikke kom fuldvoksen til verden fra det ene øjeblik til det andet, idet han måtte undfanges og vokse. Heri ligger nemlig, at heller ikke de kristne kan blive fuldkomne fra den ene dag til den anden, men må vokse i lighed med Herren. Denne vækst, som Jesus gennemgik, skete ligesom undfangelsen ved Helligånden, og derfor må også det nye $\mathrm{i}$ menigheden vokse ved Helligånden.

Da Jesus var fuldvoksen, blev han døbt i Jordan. Her dalede Helligånden nedover ham som en due, og Guds røst lød fra Himmelen:

Saa var den Helligaand ei før

Bekiendt og bosat paa Tue,

Før giennem Himlens aabne Dør

Han dalede som en Due,

$$
\text { V 216,5 }
$$

Efter dåben blev Jesus af Ånden drevet ud i ørkenen (V 328), og dernæst trådte han frem i Nazareths synagoge, hvor han bekendte, at Guds Ånd hvilede på ham (V 30,3). Således skete Jesu gerning i Guds Ånd, og da han efter at have opgivet Ånden langfredag viste sig for disciplene, kunne han ånde på dem og sige: Modtag Helligånden (IV 333,2)!

Da Jesus var uden synd og i Åndens magt, havde han også del i den guddommelige almagt, og hans ord skabte, hvad de nævnte. Ligesom Faderens Ord var Jesu ord liv og Ånd, idet Ord og Ånd blev til ét.

Der er således to sider, der skal trækkes frem i forbindelse med talen om Helligånden og Jesu liv og gerning. For det første, at Helligåndens liv og gerning forklares i Jesu liv og gerning og kan kendes derpå. Jesus er billedet på, hvad Ånden vil udføre hos ethvert menneske, og antropologi og kristologi hænger således meget nøje sammen, idet den gamle og den nye Adam ses i nær sammen- 
hæng med hinanden. For det andet skal det trækkes frem, at Jesus ved sit liv og sin gerning formidler Ånden til mennesker, idet de kun på grund af hans forsoningsdød kan modtage Ånden som en gave, der gives i dåben.

Helligåndens gerning i tiden mellem himmelfarten og genkomsten

I tiden mellem himmelfarten og genkomsten har Helligånden sin særlige virksomhed, idet denne tid er kirkens og helliggørelsens tid. I denne tid kommer Ånden i Jesu navn til mennesker, idet de ved Jesu sonedød og ved dåben får adgang til ham, og Grundtvig kan endog sige det så skarpt, at "Kun i Aanden er Gud med os og kun ved Aanden arbejder Gud hos os, fra Himmelfarts-Dagen til Domme-Dag“ (VU, VI, side 49). I denne tid er Ånden Kristi "andet jeg“ og "statholder på jorden«. I Helligåndens person er Kristus virkelig nærværende hos mennesker, og med ordet "virkelig" mener Grundtvig noget, som virker empirisk. Jesus sendte hverken paver eller "skriftkloge" til sin menighed, men han sendte dem Faderens Ånd, som skulle være hans statholder og fuldmægtig (4. s.e. påske 1853 , side 2).

Helligåndens kendetegn er Jesu ord ved dåben og nadveren. Da et menneske giver et andet menneske del i sin ånd ved sine ord, var det vigtigt for Grundtvig at have nogle ord, som var kommet fra Jesus selv, og sådanne ord, mente han, havde Jesus netop knyttet til sine indstiftelser: dåben og nadveren. I dåben og nadveren havde Jesu ord fået synlige tegn, og derfor fik disse indstiftelser overordentlig stor betydning som bærere af Ånden. På pinsedagen blev apostlene sendt ud i verden med disse tegn, og ved til stadighed at betone, at Ånden ikke taler af sig selv, men tager af Herrens og forkynder os, bruger Grundtvig et johannescitat til at udtrykke, at Ånden netop udtrykker sig gennem ordene ved dåben og nadveren. På denne måde knytter Grundtvig Guds handlinger tæt til sakramenterne og forebygger således både det sværmeri, som ikke rigtig vil anerkende, at Ånden skulle være knyttet særligt til disse ringe kendetegn, og ligeledes det sværmeri, der påstår, at Ånden skulle føje noget helt nyt til det gamle.

Helligånden blev sendt til menigheden og ikke til en enkeltperson. Ved denne påstand prøver Grundtvig at modvirke den individualisme, som har præget lutherdommen. For at forstå påstanden 
må man erindre sig, hvorledes menneskeånden ikke var givet til en enkelt, men til et samfund af mennesker. Dette skyldtes, at ånden lever i og med sproget, og derfor kan den kun leve i et levende forhold mellem mennesker. Således kan Helligånden også kun leve $i$ et levende forhold mellem mennesker og Gud og mellem mennesker ind byrdes. Først og fremmest havde Ånden jo hjemsted i samfundet mellem Faderen og Sønnen, men ved Jesu forsoning skulle dette samfund udvides til at omfatte hele menneskeslægten. Men inden dette kan ske, må Helligånden møde menneskets ånd og forklare den, og da menneskets ånd hører til i samfund mellem mennesker, kan forklaringen kun ske, ved at det ene samfund møder det andet.

I denne redegørelse for Helligåndens gerning fra himmelfarten til genkomsten må det også være rimeligt at medtage det historiske perspektiv. Grundtvig anser nemlig kirkehistorien for at være en fortsættelse af Bibelens åbenbaringshistorie (VU, VI, side 194f.). Det er dog ikke en åbenbaringshistorie, der skal ses løsrevet fra verdens historie, men den skal netop ses i nøje sammenhæng med de folkeslags historie, som kirken har levet i et vekselvirkningsforhold til (VU, VI, side 276). Grundtvig vil ikke selv skrive denne historieberetning, men antager, at der en dag vil fremstå en mand, som kan påtage sig denne gerning. Christenhedens Syvstjerne er dog et forsøg på at skrive en sådan kirkehistorie, selv om det er et beskedent forsøg, og man kan også finde forskellige spor af denne historiske indstilling $\mathrm{i}$ andre sammenhænge. Alt $\mathrm{i}$ alt mener Grundtvig, at kirkens og Helligåndens historie begyndte på pinsedagen, hvor Åndens magt var stor. I de følgende århundreder blev Åndens magt dog svagere og svagere, og først med Luther skete der en egentlig opvågnen i kirken. Imidlertid var denne opvågnen temmelig kort, idet de lutherske teologer naglede Ånden fast til papiret, og dermed blev menigheden næsten lige så livløs som før. Grundtvig mente nu, at der med hans egen tid var indtrådt en ny epoke $\mathrm{i}$ kirkens historie, idet Ånden nu igen var vågnet op til dåd.

Kirkehistorien skal imidlertid ikke som noget helt nyt åbenbare Åndens historie, thi den er jo allerede åbenbaret i Jesu liv og gerning. Derfor blev kirkens historie en gentagelse af Jesu livs historie. Ligesom Jesu liv fra fødselen til dåben er dunkel, således er kirkens historie fra apostlene til Luthers tid også dunkel (pinsedag 1843, side 7). På denne måde læser Grundtvig kirkens historie i Jesu 
historie, og samtidens historie ser han afbildet i Jesu opstandelse, idet Herrens kirkelegeme var ved at opstå. I forbindelse med denne tankegang betoner Grundtvig nemlig i særlig grad, at kirken er Kristi legeme.

Medens Jesu liv således anses for at være billedet på kirkens historie, er Jesu gerninger forbilleder på, hvad Ånden udretter i kirken. Grundtvig siger 16. s. e. trin. 1855: „Ja, Chr[istne] V[enner], det er i Sandhed opbyggeligt i Herrens synlige Gierninger ved Nains Port at see et trofast Forbillede paa hans usynlige, aandelige Gierning i sin Menighed alle Dage..."(P.G. Lindhardt: Konfrontation, side 163). Således er Jesu synlige og håndgribelige tegn og undere forbilleder på de usynlige og åndelige tegn og undere, som Helligånden gør i menigheden.

Pinsedag begyndte Ånden altså på en ny måde at virke i menneskers historie, idet han tog bolig hos os. I menigheden gør han sine frelsende gerninger og lader den vokse op i lighed med Jesu opvækst, og når legemet er blevet Åndens redskab og spejl, kommer Kristus igen for også legemligt at føre menneskeslægten tilbage til Gud, idet det gudsrige, som nu eråndeligt, skal blive håndgribeligt.

\section{Helligåndens virkninger}

Helligåndens virkninger er helt bestemt af, at skabelsens mål skal nås. I kirken skal Helligånden derfor råde bod på alle de skader, som syndefaldet har forvoldt. Hvor synden bragte død, bringer Ånden liv; hvor synden bragte mørke, bringer Anden lys osv.

Det er imidlertid interessant at bemærke, at ligesom Ånden bringer den treenige Gud nær, således er hans gerninger også trefoldige i overensstemmelse med guddommens trefoldighed. Allerede i et tidligere afsnit blev der i forbindelse med åbenbaringsopfattelsen redegjort for, at Grundtvig ville aflæse åbenbaringen af Guds væsen $\mathrm{i}$ dettes virkninger og afspejlinger i menigheden (side 51). I denne forbindelse redegør Grundtvig for, hvorledes Guds spor i menneskets verden kan ses $\mathrm{i}$ bekendelsen, dåben og nadveren svarende til Ånden, Sønnen og Faderen. Disse tegn svarer til indtrykkene tro, håb og kærlighed, der får tilsvarende udtryk i bekendelse, forkyndelse og lovsang, de såkaldte kristelige livstegn.

Svarende til at treenigheden har de hørlige og synlige tegn, som trosbekendelsen, då ben og nadveren er, har den sit usynlige, åndeli- 
ge udtryk i livskraft, sandhed og kærlighed. Helligånden er nemlig livskraften, som gør både sandheden og kærligheden virksom nærværende i menneskeslægten. Endvidere bevirker indtrykkene tro, hå $b$ og kærlighed i forening med bekendelse, dåb og nadver, at man får syndsforladelse, kødets opstandelse og et evigt liv, og dermed har man del i Guds riges retfærdighed, fred og glæde.

Således knytter Grundtvig alle disse treklange sammen i et stort system, som giver hele hans teologi en dynamik og spænding, som man sjældent ser mage til. Selve udredningerne for, hvorledes disse treklange hænger sammen, har jeg kun meget kort ridset op her, men jeg kan dog henvise til f.eks. Den Christelige Børnelaerdom (VU, VI, side $149 \mathrm{ff}$.), hvor der redegøres for den indre sammenhæng.

I stedet for at redegøre for filosofien, der ligger til grund for, at Grundtvig ser sammenhæng i disse treklange, og i det hele taget for, hvordan virkningerne af guddommen kan forekomme og ses på jorden, vil jeg opstille dem $i$ et skema, som kan give et indtryk af systemet:

\begin{tabular}{|l|l|l|}
\hline Helligånd & Ord & Fader \\
\hline Ånd & Ord & Gud \\
\hline Trosbekendelse & Dåb & Nadver \\
\hline Tro & Håb & Kærlighed \\
\hline (Livs-) Kraft & Sandhed & Kærlighed \\
\hline Hånd & Mund & Hjerte \\
\hline Bekendelse & Forkyndelse & Lovsang \\
\hline Retfærdighed & Fred & Glæde \\
\hline Syndsforladelse & Kødsopstandelse & Evigt liv \\
\hline Virksomhed & Virkning & Årsag \\
\hline
\end{tabular}

Det er svært at kommentere skemaet, idet det giver udtryk for mange forskellige aspekter. Bl.a. giver det udtryk for en stigning, når man læser fra venstre mod højre; derfor bliver menneskets vej mod Gud en vej fra venstre mod højre, hvor Guds vej mod os bliver en vej fra højre mod venstre. Venstre side udtrykker begyndelsen og højre side fuldendelsen. 
Udover de virkninger, som er udtrykt i det ovenfor stående skema, kan man selvfølgeligt finde mange andre virkninger, men de vil ofte kunne henregnes til et af de begreber, som står nævnt i skemaet. Lys, liv, nåde, trøst, visdom, osv. kan let finde udtryk $i$ et af skemaets begreber. Alt i alt kan man sige, at Ånden virker ånd med lille initial. Ånden virker sig selv, men på den måde, at det ikke er "jeg'et«, der virkes eller gives, men det er selve de guddomskræfter, som nævntes side $43 \mathrm{f}$., hvilket vil sige guddommeligt væsen.

\section{Afslutning}

Med denne artikel har jeg forsøgt at give en kort oversigt over Grundtvigs helligåndsteologi. Artiklen forsøger på ingen måde på at give svar på alle de spørgsmål, der kan melde sig i den forbindelse. Af pladshensyn har det været nødvendigt at begrænse visse dele af emnet kraftigt. Ikke mindst har begrænsningen ramt de sidste afsnit, men da flere andre redegør for den antropologiske side af Grundtvigs teologi, bl.a. som nævnt Erik Krebs Jensen, har jeg fundet det forsvarligt, at begrænsningen netop har ramt denne side af sagen. Ligeledes findes der i andre sammenhænge omtale af Åndens virkninger, så også derfor kan det forsvares, at de kun kort omtales her.

Den slutning, som denne undersøgelse af Grundtvigs helligåndsteologi må give anledning til at drage, er, at man hos Grundtvig finder en understregning af Helligåndens betydning, som man ellers kun sjældent finder i vesterlandsk teologi. Det viser sig da også ved en nærmere undersøgelse, at denne betoning af den tredie person i den treenige guddom er nødvendig, fordi Helligånden spiller en overmåde stor rolle i hele Grundtvigs forståelse af, at Gud er en nutidigt handlende virkelighed. Treenighedsteologien, som ligger bag denne forståelse, er derfor heller ikke den almindelige i den lutherske tradition, men Grundtvig har lånt forskellige elementer fra de oldkirkelige fædre af græskpåvirket herkomst. Men med denne treenighedsteologi er det lykkedes Grundtvig at gøre talen om Helligånden både forståelig og vedkommende. 